Jpn. J. Med. Mycol.

Vol. 32, Suppl. 21-30, 1991

ISSN $0916-4804$

\title{
Recent Progress in the Systematics of Basidiomycetous Yeasts
}

\author{
Takashi NAKASE, Makiko HAMAMOTO and Junta SUGIYAMA* \\ Japan Collection of Microorganisms, The Institute of Physical and Chemical \\ Research (RIKEN), Hirosawa 2-1, Wako, Saitama 351-01, Japan \\ *Institute of Applied Microbiology, The University of Tokyo, \\ 1-1-1 Yayoi, Bunkyo-ku, Tokyo 113, Japan
}

\begin{abstract}
Basidiosporogenous yeasts and basidiomycetous anamorphic yeasts have been classified based on the morphological, physiological and biochemical characteristics. Higher taxonomic ranks such as genus, family etc. are classified based on the mode of vegetative reproduction, morphological characteristics found during sexual reproduction and certain physiological characteristics such as the assimilability of inositol. Recent chemosystematic studies suggest the unreasonableness of the taxonomic system based on these characteristics. Monosaccharide compositions of the cells, especially the presence or absence of xylose, and ubiquinone systems are suggested to be more reliable systematic criteria than the mode of vegetative reproduction and morphological criteria found during the sexual reproduction on the basis of the partial sequencing study of rRNAs. Ultrastructural features well correlate with chemosystematic characteristics and are regarded as reliable systematic criteria in higher taxonomic ranks. Polyphasic approaches are essential for further progress of the systematics of basidiomycetous yeasts.

Key words : Basidiomycetous yeasts, Ballistosporous yeasts, Chemosystematics, Systematics, Mode of conidiogenesis
\end{abstract}

\section{Introduction}

The system for the classification of yeasts has been constructed based on morphological, physiological and biochemical characteristics. In recent years, modification of the taxonomic system of basidiomycetous yeasts has been suggested from chemosystematic studies.

The mode of vegetative reproduction, especially the mode of conidiogenesis, and morphological characteristics observed during sexual reproduction still play important roles in the classification of higher taxonomic ranks in basidiomycetous yeasts. However, the unreason- ableness of a classification system based on such characteristics was pointed out by several investigators on the basis of chemosystematic studies. The taxonomic rank species is now distinguished based on chemosystematic techniques such as DNA-DNA reassociation experiment, zymography, etc., in addition to the interfertility of cells. Reclassification of several genera have been proposed based mainly on chemosystematic criteria.

The progress of systematics of basidiomycetous yeasts since the publication of the $3 \mathrm{rd}$ edition of "The Yeasts, a Taxonomic Study"1) is discussed in this paper in relation to the 
evaluation of criteria used for systematics of these yeasts.

\section{Basidiomycetous anamorphic yeasts}

Basidiomycetous anamorphic yeasts have been classified by their modes of vegetative reproduction and several physiological and biochemical characteristics such as the assimilability of inositol.

In the mentioned volume published in 1984, they were classified into ten genera in two families ${ }^{1)}$. Sporobolomycetaceae includes two genera of ballistosporous yeasts, Bullera and Sporobolomyces, in which strains reproduce by budding (enteroblastic budding) in addition to reproduction by ballistospores. Pseudomycelium and ture mycelium may be formed in these genera.

The remaining basidiomycetous yeasts were classified into 8 genera in the family Cryptococcaceae which comprises both ascomycetous and basidiomycetous anamorphic yeasts. In addition to budding (enteroblastic budding) yeast cells, pseudomycelia, true mycelia and arthrospores (fission cells) may be produced in these yeasts. The genera Candida, Cryptococcus and Rhodotorula reproduce by multilateral budding. Pseudomycelium and true mycelium may be formed in these genera. Phaffia reproduces by budding and may form pseudomycelium. The mode of budding in this genus was reported as monopolar ${ }^{1)}$, however, it seems to be similar to those found in Candida, Cryptococcus and Rhodotorula. Trichosporon is characterized by the reproduction by budding and fission (formation of abundant true mycelium with arthrospores). Sarcinosporon produces sarcinalike cross-walled cells and hyphae, arthrospores and budding cells. Malassezia reproduces exclusively by monopolar budding and Sterigmatomyces reproduces exclusively by the production of buds on stalks (stalked conidia). The genera Candida and Trichosporon consist of both ascomycetous and basidiomycetous species.

The progress of systematics of several groups of basidiomycetous yeasts is discussed with the systematic evaluation of the mode of vegetative reproduction mentioned above from a chemosystematic viewpoint. Stalked conidia and ballistospores can be regarded as budding cells as stated in "The Yeasts" 1). In this paper, however, they are dealt with as different from the usual budding cell (blastoconidium) found in basidiomycetous yeasts, because the productivity of these kinds of conidia has been considered as an important taxonomic criterion by which higher taxonomic ranks of yeasts can be distinguished.

\section{A. Expansion of the world of ballistosporous} yeasts

In "The Yeasts" 1), 13 species of anamorphic ballistosporous yeasts were listed, 6 in Bullera and 7 in Sporobolomyces. Extensive isolation studies on these yeasts have been carried out over the past several years and now 47 species are recognized ${ }^{2-26)}$. Thirteen of them are included in three new genera, Bensingtonia, Ballistosporomyces and Kockovaella.

The genus Bensingtonia was described by Ingold ${ }^{10)}$ based on a single isolate. The original description so strongly resembles that of Sporobolomyces that it can hardly be discriminated from colorless strains of Sporobolomyces. Boekhout 27), however, reported that it lacks xylose in the cells and has Q-9 as the major ubiquinone and can be discriminated from Sporobolomyces in the latter criterion. Nakase and Boekhout ${ }^{28)}$ emended the diagnosis of the genus to permit the inclusion of all the ballistosporous anamorphic yeasts which lack xylose in the cells and have Q-9 as the major ubiquinone.

The genus Ballistosporomyces is characterized by reproduction by ballistospores and stalked conidia but not by budding cells ${ }^{23)}$. Stalked conidia proliferate sympodially, percurrently or in the intermediate mode. Strains of Ballistosporomyces lack xylose in the cells and have Q-10 as the major ubiquinone. This corresponds to a ballistosporous state of Kurtzmanomyces ${ }^{29)}$, which was proposed for xyloselacking and Q-10 equipped species of the genus Fellomyces ${ }^{30)}$.

The genus Kockovaella was proposed based 
Table 1. Grouping of ballistosporous yeasts

\begin{tabular}{|c|c|c|c|c|c|c|c|c|c|c|}
\hline \multicolumn{2}{|c|}{ Group } & Genus & \multirow{2}{*}{$\begin{array}{c}\begin{array}{c}\text { No. of } \\
\text { species }\end{array} \\
1\end{array}$} & \multirow{2}{*}{$\begin{array}{c}\begin{array}{c}\text { Xylose } \\
\text { in cells }\end{array} \\
-\end{array}$} & \multirow{2}{*}{$\begin{array}{l}\begin{array}{l}\text { Ubi- } \\
\text { quinone }\end{array} \\
\text { Q-10(H2) }\end{array}$} & \multirow{2}{*}{$\begin{array}{c}\begin{array}{c}\text { Stalked } \\
\text { conidia }\end{array} \\
-\end{array}$} & \multirow{2}{*}{$\begin{array}{c}\begin{array}{c}\text { Ballisto- } \\
\text { spores }\end{array} \\
\text { asy }\end{array}$} & \multirow{2}{*}{$\begin{array}{c}\begin{array}{c}\text { Carote- } \\
\text { noids }\end{array} \\
+\end{array}$} & \multirow{2}{*}{$\frac{2 \mathrm{KG}}{-}$} & \multirow{2}{*}{$\frac{\begin{array}{l}\text { Non-ballistosporous } \\
\text { state }\end{array}}{\text { (Rhodotorula })}$} \\
\hline 1 & & Sporobolomyces & & & & & & & & \\
\hline \multirow[t]{3}{*}{2} & $2 a$ & Sporobolomyces & $15 *$ & - & $\mathrm{Q}-10$ & - & asy & $+/(-)$ & - & Rhodotorula \\
\hline & $2 b$ & Sporobolomyces & 5 & - & $Q-10$ & - & asy & - & + & Rhodotorula \\
\hline & $2 \mathrm{c}$ & Sporobolomyces & 2 & - & $\mathrm{Q}-10$ & - & asy & - & - & Rhodotorula \\
\hline 3 & & Bensingtonia & 9 & - & Q-9 & - & asy/sy & $-1+$ & $-1+$ & Rhodotorula \\
\hline 5 & & Ballistosporomyces & 2 & - & $\mathrm{Q}-10$ & + & asy & + & - & Kurtzmanomyces \\
\hline \multirow{2}{*}{4} & $4 \mathrm{a}$ & Bullera & 11 & + & $\mathrm{Q}-10$ & - & sy & $-/+$ & + & Cryptococcus \\
\hline & $4 \mathrm{~b}$ & Bullera & 3 & + & $\mathrm{Q}-10$ & - & asy/sy & $(+)$ & + & Cryptococcus \\
\hline 6 & & Kockováella & 2 & + & $\mathrm{Q}-10$ & + & asy/sy & + & + & (Fellomyces) \\
\hline
\end{tabular}

* Sporidiobolus species are included.

on three isolates from plants in Thailand ${ }^{26)}$. It is characterized by the reproduction by ballistospores, stalked conidia and budding cells, and by the presence of xylose in the cells and Q-10 as the major ubiquinone. This genus resembles the ballistosporous state of Fellomyces though budding cells are not found in the latter.

Forty-seven species of ballistosporous anamorphic yeasts were tentatively classified into 6 groups based on the presence or absence of xylose in the cells, major ubiquinones, and the modes of vegetative reproduction. Each group corresponds to the taxonomic rank genus (Table 1).

The presence or absence of xylose in the cells should be regarded as a criterion to separate the taxonomic rank family or order. Weijman and Rodrigues de Miranda ${ }^{31}$ ) investigated the presence of xylose in the genera Bullera and Sporobolomyces by gas-liquid chromatographic analysis of derivatized whole cell hydrolyzates. They found xylose in the majority of Bullera strains but not in most Sporobolomyces strains and suggested the transfer of Sporobolomyces puniceus, a xylose-containing species, to Bullera. However, they obtained insignificant results in Bullera salicina, Bullera tsugae and Sporobolomyces gracilis. Suzuki and Nakase ${ }^{32)}$ investigated these three strains by an improved technique using high performance liquid chromatography and confirmed the absence of xylose in their cells. Based on the presence or absence of xylose, B. tsugae and B. salicina were transferred to Sporobolomyces ${ }^{33}$ ) and S.puniceus was transferred to Bullera ${ }^{9)}$.

Weijman and Rodrigues de Miranda ${ }^{31}$ reported that the carbohydrate patterns recorded for the xylose-containing Bullera strains closely resemble the patterns of Cryptococcus, Trichosporon, Filobasidium and other basidiomycetous fungi presently classified in Filobasidiaceae.

The type of ubiquinone system is considered to be a criterion to define the taxonomic rank genus ${ }^{1)}$. Each group in Table 1 has its own major ubiquinone. Sporobolomyces elongatus is placed in group 1 and the remaining Sporobolomyces species are placed in group 2 . The former species has Q-10 $\left(\mathrm{H}_{2}\right)$ as the major ubiquinone and differs from the remaining species of Sporobolomyces in this respect. A close relationship of this species to Erythrobasidium hasegawae is suggested and is discussed later. It might represent a genus different from Sporobolomyces.

By the finding of yeasts belonging to the genera Ballistosporomyces and Kockovaella, the modes of conidiogenesis became complicated as compared with those shown in "The Yeasts" ${ }^{1)}$. The modes of conidiogenesis found in basidiomycetous anamorphic yeasts are summarized in Fig. 1. Combinations of the modes of conidiogenesis, allow basidiomycetous anamorphic yeasts to be classified into 9 
groups. We assume that yeasts belonging to groups 1 to 6 have an ability to carry out these three kinds of conidiogenesis: (multilateral) budding, production of stalked conidium, and production of ballistospores, when suitable conditions are provided. Namely, we assume that ballistosporous yeasts do not comprise a special group of basidiomycetous yeasts but represent a ballistosporous aspect of various of these yeasts.

B. Relationships between ballistosporous and non-ballistosporous yeasts.

It is well known that ballistospore-forming ability is easily lost during maintenance. In fact, type strains of Bullera singularis, Bullera tsugae, Sporobolomyces albo-rubescens, Sporobolomyces gracilis and Sporobolomyces puniceus were reported to show no ballistosporous ability ${ }^{1)}$. Even in freshly isolated strains, ballistosporous ability is often very poor or completely lacking. Nakase and Suzuki ${ }^{6}$ ) isolated 13 strains of Bullera crocea from dead leaves of a rice plant, Oryza sativa. Ballistospore-formation was abundant in 3 strains, moderate in 2 strains, and poor in 3 strains. The remaining 5 strains did not produce ballistospores on any media examined. Non-ballistosporous strains showed characteristics identical to ballistosporous strains except for ballistosporous ability therefore must be identified as B. crocea in spite of the lack of ballistospores.

When ballistospores cannot be observed in ballistosporous yeasts strains, we cannot discriminate them from non-ballistosporous yeasts. Non-ballistosporous strains are identified as

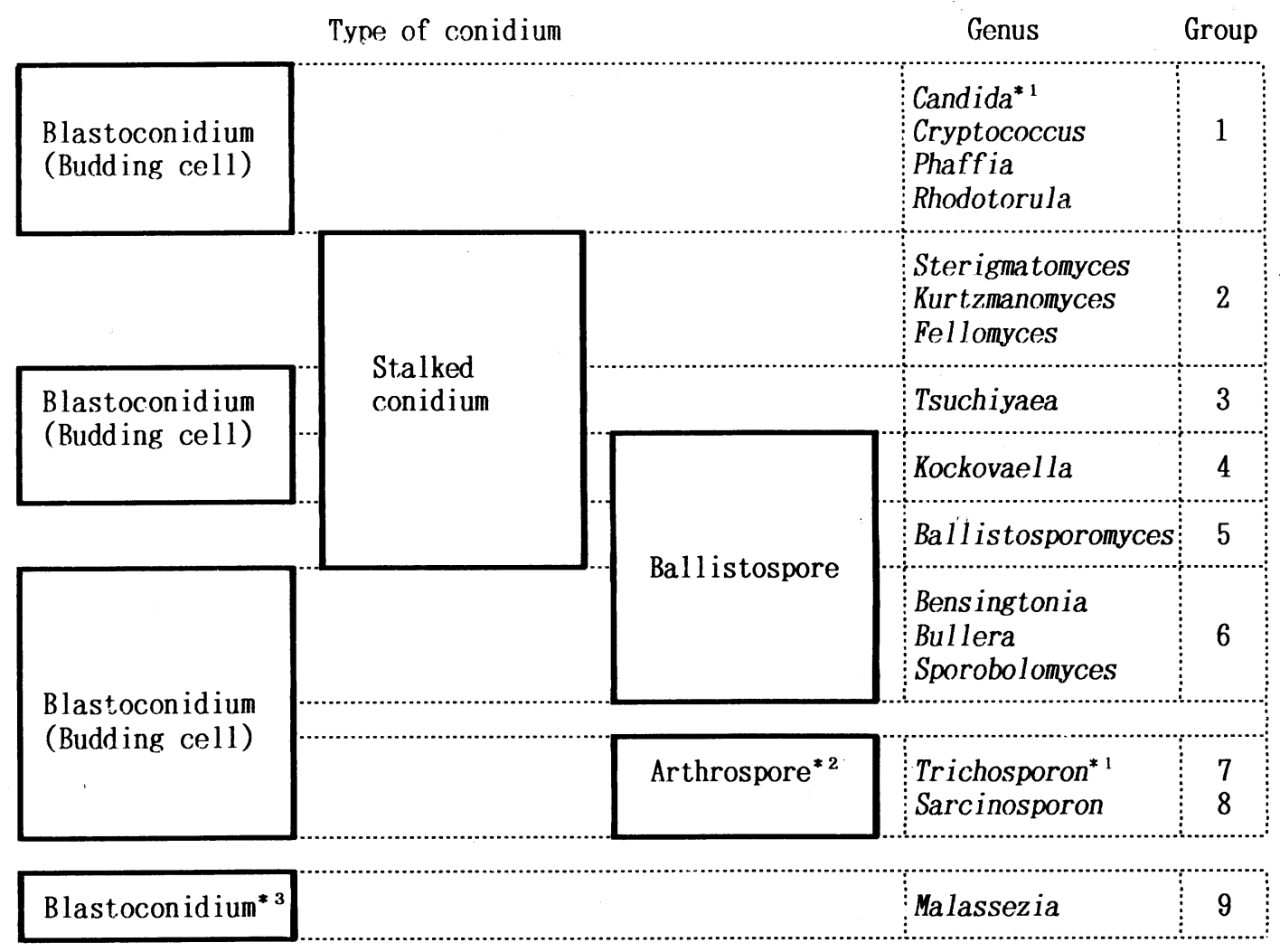

*1 in parte *2 Fission *3 Monopolar budding

Fig. 1. The mode of conidiogenesis found in genera of basidiomycetous anamorphic yeasts. 
Rhodotorula, Kurtzmanomyces, Cryptococcus and probably as Fellomyces as shown in Table 1. Yamazaki and Komagata ${ }^{34)}$ reported that a strain of Cryptococcus albidus var. albidus, a non-ballistosporous yeast, showed similar enzyme patterns to Bullera alba, a ballistosporous yeast, in slab-gel electrophoresis. We can easily assume a close relationship between ballistosporous taxa and their corresponding non-ballistosporous taxa.

Based on this assumption, Nakase et al. ${ }^{26)}$ compared the sequences of 170 bases in the positions from 1451 to 1618 of $18 \mathrm{~S}$ rRNA from strains of Kockovaella with strains of Bullera and xylose-positive, stalked conidiumforming non-ballistosporous yeasts. A dendrogram prepared based on the base difference is shown in Fig. 2. Strains of Kockovaella, Fellomyces and Sterigmatosporidium comprise a single cluster and base differences among these yeasts were found to be two to four. This suggested a close phylogenetic relationship among these three genera and implies that the presence or absence of ballistospores and budding cells is not as important a taxonomic criterion as has long been believed.

It seems more reasonable to combine Kockovaella and Fellomyces in a single genus than to deal with them as different genera. However, we hesitate to do so yet. When it is once done, the same principle must be applied to the remaining groups of basidiomycetous anamorphic yeasts, for example, we have to combine Bullera and Cryptococcus, and Sporobolomyces and Rhodotorula. Apparently, there is little merit to do so because a respective combined genus increases its heterogeneity. Further, the sequence of 170 bases corresponds to just about $10 \%$ of the whole molecule. Any great change in the system of classification should be performed only when sufficient chemosystematic and molecular systematic information has been accumulated.

\section{Stalked conidium-forming yeasts}

A single genus Sterigmatomyces was listed in stalked conidium-forming yeasts in "The Yeasts" ${ }^{1)}$. Yamada and Banno ${ }^{30)}$ excluded spe- cies having Q-10 as the major ubiquinone and liberating conidium by end-break from Sterigmatomyces and proposed a new genus Fellomyces for these species. Later, Yamada et al. 29,35) divided stalked conidium-forming yeasts into 4 genera based on the presence or absence of xylose in the cells, ubiquinone types and the position of the liberation of conidium from the stalk.

Sterigmatosporidium, which has been considered a teleomorphic counterpart of Sterigmatomyces, was regarded as a teleomorph of Fellomyces ${ }^{30}$. A close relationship of Sterigmatosporidium to Fellomyces was suggested based on the comparison of the partial base sequences of 18S rRNA as mentioned above (Fig. 2). This classification was supported by recent studies on the partial sequence of $18 \mathrm{~S}$ and $25 \mathrm{~S}$ rRNA from stalked conidium-forming yeasts $36,37)$.

D. Other basidiomycetous anamorphic genera

Before publication of "The Yeasts" 1 , Moore 38) proposed a new genus Vanrija for basidiomycetous species included in Candida and Torulopsis. This genus is not adopted in the monograph. Apparently, Vanrija includes a variety of basidiomycetous anamorphic yeasts of supposedly diverse phylogenetic origins.

Weijman and Rodrigues de Miranda ${ }^{39}$ found that species in the genus Candida can be separated into 3 groups based on the monosaccharide component of whole cell hydrolyzates. Cells of ascomycetous species are composed mainly of mannose and lack rhamnose, fucose and xylose. Basidiomycetous species are divided into two groups. One group contains xylose and does not contain a large amount of mannose; this pattern is characteristic of Cryptococcales and Tremellales. The other group contains fucose and/or rhamnose and a relatively large amount of mannose; this pattern is characteristic of Sporobolomycetaceae. This caused Weijman et al. 40) to transfer species of the former group of basidiomycetous yeasts to a redefined genus Cryptococcus and those of the latter to a redefined genus Rhodotorula.

As shown for ballistosporous yeasts, the 

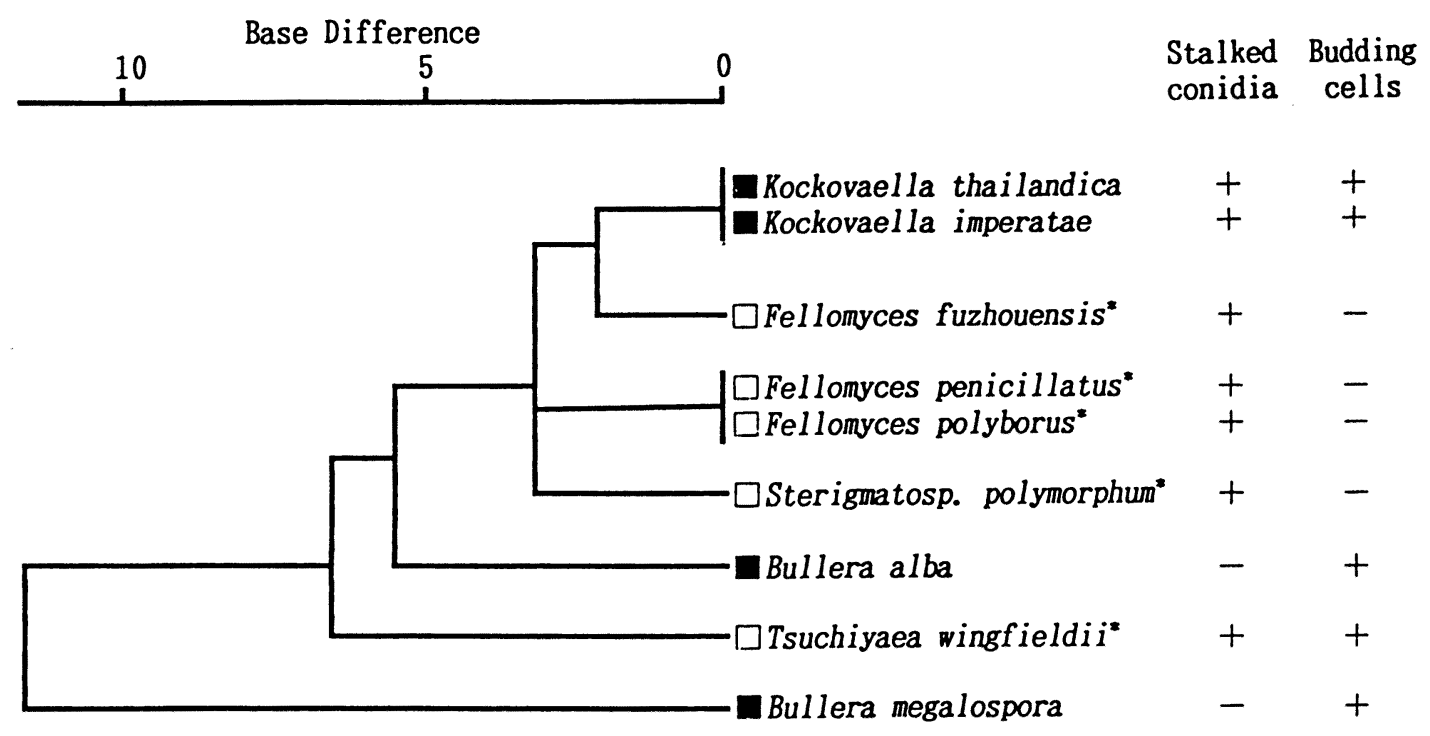

Ballistosporous $\square$ Non-ballistosporous

* Data from references 36 and 37 .

Fig. 2. Dendrogram based on the base difference of sequences of positions 1451 through 1618 of $18 \mathrm{~S}$ rRNA of strains of Kockovaella and supposedly related genera (prepared by unweighted pair-group method).

monosaccharide composition of cells, especially the presence or absence of xylose, seems a better criterion by which to separate the taxonomic rank genus in basidiomycetous yeasts than the assimilation of inositol and the productivity of mycelium and pseudomycelium now employed to separate the three genera mentioned above.

\section{Basidiosporogenous yeasts}

Basidiosporogenous yeasts were classified into 3 groups, Filobasidiaceae, teliospore-forming yeasts, and Tremellales with a yeast phase. Among them, the genera Rhodosporidium and Leucosporidium in teliospore-forming yeasts show great heterogeneities. Respective genus includes both xylosecontaining and xyloselacking species, as well as species having 3 different kinds of major ubiquinones, Q-8, Q9 , and $\mathrm{Q}-10$.

Xylose-containing and Q-8-equipped species in Rhodosporidium are now placed in Cystofilobasidium. Oberwinkler et al. ${ }^{41)}$ transferred Rhodosporidium bisporidiis and Rhodosporidium capitatum to a newly established genus
Cystofilobasidium, which was placed in Filobasidiaceae, because yeasts in this genus produce holobasidia, sessile basidiospores and doliporelike septal pores, in spite of the fact that they can produce teliospores. Later, Hamamoto et al. ${ }^{42)}$ transferred Rhodosporidium infirmominiatum to Cystofilobasidium.

Rhodosporidium malvinellum, a xylose-lacking, Q-9-equipped species, was transferred to a newly proposed genus Kondoa based on the difference of base sequences of $18 \mathrm{~S}$ and $26 \mathrm{~S}$ rRNAs ${ }^{43)}$. A two-celled basidium is formed in this genus. Very recently, Suh and Sugiyama (unpublished data) found that this species had septal pores as seen in species of Atractogloea in the Atractiellales. This finding reinforces this proposal.

Four species of xylose-containing and Q-8equipped yeasts in Leucosporidium were transferred to Mrakia, a newly established genus ${ }^{44)}$. The basidial form in the genus is holobasidium. Mrakia was placed in Filobasidiaceae in spite of its production of teliospores. The septal pore structure of Mrakia frigida and Mrakia 
Table 2. Grouping of teliospore-forming yeasts and related genera

\begin{tabular}{|c|c|c|c|c|c|}
\hline Genus & $\begin{array}{l}\text { Xylose } \\
\text { in cells }\end{array}$ & $\begin{array}{l}\text { Major } \\
\text { ubiquinone }\end{array}$ & Teliospore & $\begin{array}{l}\text { Basidial } \\
\text { form }\end{array}$ & $\begin{array}{l}\text { Septal pore } \\
\text { structure }\end{array}$ \\
\hline \multicolumn{6}{|l|}{ Group A* } \\
\hline Kondoa & - & Q-9 & + & phragmo & simple pore \\
\hline Leucosporidium & - & Q-9/Q-10 & + & phragmo & simple pore \\
\hline Rhodosporidium & - & $\mathrm{Q}-9 / \mathrm{Q}-10$ & + & phragmo & simple pore \\
\hline Sporidiobolus & - & $\mathrm{Q}-10$ & + & holo/phragmo & simple pore \\
\hline Erythrobasidium & - & $\mathrm{Q}-10\left(\mathrm{H}_{2}\right)$ & - & holo & simple pore \\
\hline \multicolumn{6}{|l|}{ Group B* } \\
\hline Mrakia & + & $\mathrm{Q}-8$ & + & holo & primitive dolipore \\
\hline Cystofilobasidium & + & $\mathrm{Q}-8$ & + & holo & primitive dolipore \\
\hline Filobasidium & + & $\mathrm{Q}-9 / \mathrm{Q}-10$ & - & holo & primitive dolipore \\
\hline Filobasidiella & + & $\mathrm{Q}-10$ & - & holo & primitive dolipore \\
\hline
\end{tabular}

*Group A, Ustilaginale affinity; Group B, Filobasidiaceae.

nivalis is primitive dolipore (Suh and Sugiyama, unpublished data).

In 1988, Hamamoto et al. ${ }^{45)}$ found a sexual stage of Rhodotorula hasegawae and proposed a new genus Erythrobasidium for this species. Erythrobasidium is characterized by Q-10 $\left(\mathrm{H}_{2}\right)$, the absence of xylose in the cells, the lack of teliospores and the production of holobasidia. They tentatively placed it in Filobasidiaceae based on the morphological characteristics which are similar to yeasts in Filobasidiaceae. This genus differs from other yeasts in Filobasidiaceae in its lack of xylose in the cells. The septal pore structure of Erythrobasidium hasegawae was found to be simple pore (Suh and Sugiyama, unpublished data).

Monosaturated ubiquinone Q-10 $\left(\mathrm{H}_{2}\right)$ is popular in Ascomycotina but rare in Basidiomycotina. In yeasts, it was found in two species, Erythrobasidium hasegawae and Sporobolomyces elongatus, as the major ubiquinone ${ }^{46,47)}$. Takematsu et al. (unpublished data) compared the partial sequence of $18 \mathrm{~S}$ rRNA of these two species in the positions from 1451 to 1618 . They found that the RNAs have an identical base sequence in this region, strongly suggesting a close relationship between these two species. Erythrobasidium is assumed to be rel ated to xylose-negative teliospore-forming yeasts though it does not produce teliospores. As mentioned above, the septal pore structure of Erythrobasidium hasegawae is of the simple pore type and differs from those of Filobasidiaceae.

The salient characteristics of genera in "teliospore-forming yeasts" and Filobasidiaceae are summarized in Table 2. These yeasts are classified into 2 groups.

Group A comprises five genera. Xylose is not found in the cells and septal pore structure is simple pore. Teliospores are produced in 4 genera but not 1 genus. The basidial form is usually, phragmobasidium but sometimes holobasidium.

Group B comprises four genera. Xylose is found in the cells and septal pore structure is primitive dolipore. Basidial form is holobasidium. This classification is supported by the partial sequencing study of $18 \mathrm{~S}$ rRNA (Joo, Sugiyama and Komagata, unpublished data).

The presence or absence of xylose in the cells and the septal pore structures are cons idered to be more reliable taxonomic criteria than the teliospore-forming ability and basidial form in the classification of higher taxonomic ranks such as genus, family, etc.

\section{Conclusion}

Based on extensive studies on carbohydrate patterns of yeasts and yeast-like fungi, Weijman and Golubev ${ }^{48)}$ presented cell wall categories of yeasts and yeast-like fungi which showed the 
relationships of carbohydrate patterns to taxonomic ranks, families and classes. They considered that the presence or absence of xylose, fucose or rhamnose is important in basidiomycetous yeasts and yeastlike fungi, together with the amount of mannose and chitin. The carbohydrate pattern of the cells, as a reflection of the cell wall structure, is considered to be an important taxonomic crite rion in yeasts.

Recent studies on the sequences of rRNAs revealed the significance of this technique. As with the definition of taxonomic rank species, chemosystematic approaches are essential for the systematics of higher taxonomic ranks such as genus, family, order, etc., of basidiomycetous yeasts.

van der Walt and von Arx ${ }^{49)}$ emphasized the use of ultrastructural characters in yeast systematics. They discussed the significance of ultrastructural features of the cell walls, septa and ascospores. As discussed, a good correlation is observed between ultrastructure of septal pores and chemosystematic criteria. Together with chemosystematic studies, ultrastructural studies will provide invaluable information on yeast systematics.

Polyphasic approaches appear to be required for further progress in the systematics of basidiomycetous yeasts. Chemosystematic approaches are believed to be especially important for the establishment of a rational classification system.

\section{References}

1) Kreger-van Rij NJW (ed): The Yeasts, a Taxonomic Study, 3rd ed., p.1-1082, Elsevier Sci Publ, Amsterdam, 1984.

2) Li M : Studies on Sporobolomycetaceae. I. Taxonomy of Bullera. Acta Microbiol Sinica 22 : 17-25, 1982.

3) Shivas RG and Rodrigues de Miranda L : Two new species of the genus Sporobolomyces and a new Rhodotorula species from leaf surfaces. Antonie van Leeuwenhoek 49 : 159-166, 1983.

4) Buhagiar RWM, Yarrow D and Barnett JA : Bullera crocea and Bullera armeniaca, two new yeasts from fruit and vegetables. J Gen Microbiol 129 : 3149-3155, 1983.

5) Johri BN and Bandoni RJ : Taxonomy of the sporobolomycetous genus Bullera. Proc Int Symp Taxon Fungi, Madras 2:536547, 1984.

6) Nakase $T$ and Suzuki $M$ : Ballistosporeforming yeasts found on the surface of the Japanese rice plant, Oryza sativa L. $J$ Gen Appl Microbiol 31 : 457-474, 1985.

7) Nakase $T$ and Suzuki $M$ : Bullera derxii sp. nov. and Bullera pseudoalba sp. nov isolated from dead leaves of Oryza sativa and Miscanthus sinensis. J Gen Appl Microbiol 32 : 125-135, 1986.

8) Nakase $T$ and Suzuki M : Bullera intermedia sp. nov. and Sporobolomyces oryzicola sp. nov. isolated from dead leaves of Oryza sativa. J Gen Appl Microbiol 32 : 149-155, 1986.

9) Nakase $\mathrm{T}$ and Suzuki M : Bullera megalospora, a new species of yeast forming large ballistospores isolated from dead leaves of Oryza sativa, Miscanthus sinensis and Sasa sp. in Japan. J Gen Appl Microbiol 32 : 225-240, 1986.

10) Ingold CT : Bensingtonia ciliata gen. et sp. nov., a ballistosporic fungus. Trans $\mathrm{Br}$ Mycol Soc 86 : 325-328, 1986.

11) van der Walt JP, Ferreira NP and Richards PDG : New basidiomycetous yeasts from Southern Africa I : Sporobolomyces kluyveri-nielii sp. nov. Antonie van Leeuwenhoek 52 : 431-436, 1986.

12) Nakase $T$ and Suzuki $M:$ Sporobolomyces inositophilus, a new species of ballistosporous yeast isolated from a dead leaf of Sasa sp. in Japan. Antonie van Leeuwenhoek 53 : 245-251, 1987.

13) Nakase $T$ and Suzuki M : Sporobolomyces griseoflavus and Sporobolomyces sasicola, two new species of ballistosporous yeasts isolated from dead leaves of Sasa sp. in Japan. J Gen Appl Microbiol 33 : 167-175, 1987.

14) Nakase $T$ and Suzuki $M$ : Bulleravariabilis, a new species of yeast with uniquely-shaped ballistospores isolated from various plant materials. J Gen Appl Microbiol 33 : 343$354,1987$.

15) Nakase $T$ and Suzuki $M:$ Sporobolomyces 
naganoensis, a new species of ballistosporous yeast equipped with ubiquinone-9, isolated from a dead leaf of Sasa sp. in Japan. Trans Mycol Soc Jpn $28: 1-8,1987$.

16) Nakase $T$ and Suzuki $M$ : Studies on ballistospore-forming yeasts from the dead leaves of Miscanthus sinensis with descriptions of new species, Sporobolomyces miscanthi, Sporobolomyces subroseus, and Sporobolomyces weijmanii. J Gen Appl Microbiol 33 : 177-196, 1987.

17) Nakase $T$ and Suzuki M : Sporobolomyces yuccicola, a new species of ballistosporous yeast equipped with ubiquinone-9. Antonie van Leeuwenhoek $54: 47-55,1988$.

18) Nakase $T$, Itoh $M$ and Suzuki $M$ : Sporobolomyces falcatus sp. nov., isolated from a dead leaf of Miscanthus sinensis in Japan. Trans Mycol Soc Jpn 28 : 295-301, 1987.

19) Nakase T, Suzuki $M$ and Itoh $M$ : Sporobolomyces yamatoanus, a new species of ballistosporous yeast equipped with ubiquinone- 9 isolated from dead leaves of various plant materials in Japan. $J$ Gen Appl Microbiol 33 : 445-454, 1987.

20) van der Walt JP, Yamada $Y$, Ferreira NP and Richards PDG : New basidiomycetous yeasts from Southern Africa. III. Sporobolomyces phyllomatis sp. nov. (Sporobolomycetaceae). Antonie van Leeuwenhoek 54 : 201-206, 1988.

21) van der Walt JP, Yamada Y, Ferreira NP and Richards PDG : New basidiomycetous yeasts from Southern Africa. IV. Sporobolomyces phylladus sp. nov., characterized by the coenzyme Q9 system (Sporobolomycetaceae). Antonie van Leeuwenhoek 55 : 189-195, 1989.

22) Nakase $T$, Itoh $M$ and Sugiyama $J: B e n-$ singtonia ingoldii sp. nov., a ballistosporeforming yeast isolated from Knightia excelsa collected in New Zealand. J Gen Appl Microbiol 35 : 53-58, 1989.

23) Nakase $T$, Okada G, Sugiyama J, Itoh $M$ and Suzuki M : Ballistosporomyces, a new ballistospore-forming anamorphic yeast genus. J Gen Appl Microbiol 35 : 289-309, 1989.

24) Nakase T, Itoh $M$, Takematsu $A$ and Bandoni RJ : Bullera miyagiana, a new species of ballistospore-forming yeast isolated from Abies firma collected in Japan. J Gen Appl Microbiol $36: 33-39,1990$.

25) Nakase $T$, Itoh $M$, Suzuki $M$ and Bandoni RJ : Sporobolomyces lactophilus sp. nov., a ballistospore-forming yeast isolated from Abies firma collected in Japan. Trans Mycol Soc Jpn $31: 159-167,1990$.

26) Nakase $T$, Itoh $M$, Takematsu A, Mikata $\mathrm{K}$, Banno I and Yamada Y : Kockovaella, a new ballistospore-forming anamorphic yeast genus. J Gen Appl Microbiol, 37 : 175-197, 1991.

27) Boekhout $\mathrm{T}$ : Taxonomy of anamorphs of smut fungi. In The expanding realm of yeast-like fungi (de Hoog GS, Smith MTh and Weijman ACM, ed.) p.137-149, Elsevier Sci Publ, Amsterdam, 1987.

28) Nakase $T$ and Boekhout $T$ : Emendation of the genus Bensingtonia Ingold. J Gen Appl Microbiol 34 : 433-437, 1988.

29) Yamada $Y$, Itoh $M$, Kawasaki $H$, Banno $\mathrm{I}$ and Nakase $\mathrm{T}$ : Kurtzmanomyces gen. nov., an anamorphic yeast genus for the Q10-equipped organism whose conidium is freed by end-break in the sterigma which branches or elongates to produce additional conidia and whose cells contain no xylose. J Gen Appl Microbiol 34 : 503-506, 1988.

30) Yamada Y and Banno I : Fellomyces, a new anamorphic yeast genus for the Q10equipped organisms whose conidium is freed by an end-break in the sterigma. J Gen Appl Microbiol 30 : 523-525, 1984.

31) Weijman ACM and Rodrigues de Miranda $\mathrm{L}$ : Xylose distribution within and taxonomy of the genera Bullera and Sporobolomyces. Antonie van Leeuwenhoek 49 : 559-562, 1983.

32) Suzuki $M$ and Nakase $T$ : The distribution of xylose in the cells of ballistosporous yeasts-Application of high performance liquid chromatography without derivatization to the analysis of xylose in whole cell hydrolysates. J Gen Appl Microbiol $34: 95-103,1988$.

33) Nakase $T$ and Itoh $M$ : Two new combinations of Ballistospore-forming yeasts: Sporobolomyces tsugae comb. nov. and Sporobolomyces salicinus comb. nov. J Gen Appl Microbiol 34 : 499-502, 1988. 
34) Yamazaki $\mathrm{M}$ and Komagata $\mathrm{K}$ : An electrophoretic comparison of enzymes of ballistosporogenous yeasts. J Gen Appl Microbiol 29 : 115-143, 1983.

35) Yamada $Y$, Kawasaki H, Itoh M, Banno $\mathrm{I}$ and Nakase T:Tsuchiyaea, gen. nov., an anamorphic yeast genus for the Q9equipped organism whose reproduction is either by enteroblastic budding or by the formation of conidia which are disjointed at a septum in the mid-region of the sterigmata and whose cells contain xylose. $J$ Gen Appl Microbiol 34 : 507-510, 1988.

36) Guého E, Kurtzman CP and Peterson SW : Phylogenetic relationships among species of Sterigmatomyces and Fellomyces as determined from partial rRNA sequences. Int J Syst Bacteriol $40: 60-65,1990$.

37) Yamada $Y$, Kawasaki $H$, Nakase $T$ and Banno I: The phylogenetic relationship of the conidium-forming anamorphic yeast genera Sterigmatomyces, Kurtzmanomyces, Tsuchiyaea and Fellomyces and the teleomorphic yeast genus Sterigmatosporidium on the basis of the partial sequences of $18 \mathrm{~S}$ and $26 \mathrm{~S}$ ribosomal ribonucleic acids. Agric Biol Chem 53 : 2993-3001, 1989.

38) Moore RT : Taxonomic proposals for the classification of marine yeasts and other yeast-like fungi including the smuts. Bot Mar 23 : 361-373, 1980.

39) Weijman ACM and Rodrigues de Miranda L : Carbohydrate patterns of Candida, Cryptococcus and Rhodotorula species. Antonie van Leeuwenhoek 54 : 535-543, 1988.

40) Weijman ACM, Rodrigues de Miranda L and van der Walt JP: Redefinition of Candida Berkhout and the consequent emendation of Cryptococcus Kützing and Rhodotorula Harrison. Antonie van Leeuuwenhoek $54:$ 545-553, 1988.

41) Oberwinkler F, Bandoni RJ, Blanz $P$ and Kisimova-Horovitz L : Cystofilobasidium: a new genus in the Filobasidiaceae. System Appl Microbiol 4 : 114-122, 1983.

42) Hamamoto $M$, Sugiyama $J$ and Komagata $\mathrm{K}$ : Transfer of Rhodosporidium infirmominiatum to the genus Cystofilobasidium as Cystofilobasidium infirmominiatum nomb. nov. J Gen Appl Microbiol $34: 271$ $-278,1988$.

43) Yamada $Y$, Nakagawa $Y$ and Banno I : The phylogenetic relationship of the Q9equipped species of the heterobasidiomycetous yeast genera Rhodosporidium and Leucosporidium based on the partial sequences of $18 \mathrm{~S}$ and $26 \mathrm{~S}$ ribosomal ribonucleic acids: The proposal of a new genus Kondoa. J Gen Appl Microbiol $35: 377-385$, 1989.

44) Yamada Y and Komagata K : Mrakia gen. nov., a heterobasidiomycetous yeast genus for the Q8-equipped, self-sporulating organisms which produce a unicellular metabasidium, formerly classified in the genus Leucosporidium. J Gen Appl Microbiol $33: 455-457,1987$.

45) Hamamoto M, Sugiyama J and Komagata $\mathrm{K}$ : Transfer of Rhodotorula hasegawae to a new basidiomycetous genus Erythrobasidium as Erythrobasidium hasegawae comb. nov. J Gen Appl Microbiol 34: 279 $-287,1988$.

46) Yamada $Y$ and Kondo K : Coenzyme Q system in the classification of the yeast genera Rhodotorula and Cryptococcus, and the yeast-like genera Sporobolomyces and Rhodosporidium. J Gen Appl Microbiol 19 : 59-77, 1973.

47) Nakase $T$ and Suzuki $M$ : The ubiquinone system in strains of species in the ballistospore-forming yeast genera Sporidiobolus, Sporobolomyces and Bullera. J Gen Appl Microbiol 32 : 251-258, 1986.

48) Weijman ACM and Golubev I : Carbohydrate patterns and taxonomy of yeasts and yeast-like fungi. In The Expanding Realm of Yeast-like Fungi (de Hoog GS, Smith M Th and Weijman ACM, ed.) p. 361-371, Elsevier Sci Publ, Amsterdam, 1987.

49) van der Walt JP and von Arx JA: Use of ultrastructural characters in yeast systematics. S Afr J Microbiol 81 : 156-159, 1985. 